Gizi Indon 2008, 31(1):9-22 Kajian perbedaan prevalensi balita kurus

Sandjaja

\title{
KAJIAN PERBEDAAN PREVALENSI BALITA KURUS DAN PENDEK MENURUT STANDAR WHO 2005 DIBANDING NCHS: Analisis Data SKRT 2004
}

\author{
Sandjaja \\ Pusat Penelitian dan Pengembangan Gizi dan Makanan, Depkes RI
}

\section{ABSTRACT \\ THE DIFFERENCE IN THE PREVALENCE OF WASTING AND STUNTING IN CHLIDREN AGE 0-59 MONTHS BY USING NCHS AND NEW WHO ANTHROPOMETRIC STANDARD: Re-analysis of Indonesian Household Health Survey 2004}

WHO introduced new Child Growth Standard for children $0-60$ months of age in the early 2006 based on Multi-Centre Growth Reference Study (MGRS) in 6 countries: Brazil, Ghana, India, Norway, Oman and the United States of America involving healthy children living in healthy environment that provide possibility for them to grow according to their genetic potential. WHO recommended that the standard be used as a new anthropometric reference replacing the existing NCHS-WHO child growth reference. However, some experts demand to evaluate the standard, before Indonesia adopts it in the nutrition program. This paper tries to compare the consequence of adopting new WHO standard to the magnitude of stunting and wasting. The main objective of the paper is to re-analyze the existing anthropometric data on children aged 0-59 months by using both NCHS-WHO reference and new WHO standard on the prevalence of wasting (W/L or W/H) and stunting $(H / A)$. This re-analysis is based on anthropometric data of 3,316 children age below 5 years old from Household Health Survey 2004. Child weight and length/height were converted into z-scores of W/H and $\mathrm{H} / \mathrm{A}$ by using both NCHS and new WHO Growth Standard, and compared the prevalence of wasting and stunting. The results showed that the prevalence stunting is higher by using new WHO Growth Standard (28.6\%) compared to that by using NCHS growth references (24.1\%). The difference in the prevalence varied between sex from $4.5-4.7 \%$ and across age groups from 1.3-9.2\%. Similar results also found for the prevalence of wasting. The prevalence of wasting by using WHO Growth Standard and NCHS growth references was $15.1 \%$ and $13.8 \%$ respectively. The difference in the prevalence varied between sex from $0.8-2.1 \%$ and across age groups which varied fourfold ( $21.0 \%$ and $5.6 \%$ ) for children age below 6 month old and only $1.7 \%$ for children age 48-59 month old.

Keywords: anthropometric standard, stunted, wasted, height for age, weight for height

\section{PENDAHULUAN}

$\mathrm{P}$ ada tahun 2005 badan kesehatan dunia, World Health Organization (WHO), mengeluarkan standar antropometri WHO Child Growth Standards (WHO-GS). Standar antropometri tersebut didasarkan pada penelitian Multi-Centre Growth Reference Study (MGRS) in 6 negara yaitu Brazil, Ghana, India, Norway, Oman dan Amerika Serikat. Selanjutnya WHO- South East Asean Regional Office (WHO-SEARO) melakukan sosialisasi standar baru tersebut di Bangkok pada tahun
2006. WHO mendorong agar negara-negara peserta mengadopsi standar ini karena adanya keragaman pemakaian standar antropometri di berbagai negara.

Indonesia sejak tahun 1990 menggunakan the United States National Center for Health Statistics (NCHS) Growth Reference sebagai standar antropometri gizi untuk balita. Hal tersebut tertuang dalam Surat Keputusan Menteri Kesehatan nomor 920 tahun 2002. Standar antropometri WHO yang baru tersebut mempunyai implikasi yang luas jika digunakan di Indonesia. Perbedaan penggunaan standar akan menyebabkan perubahan prevalensi status 
gizi anak usia 0-59 bulan (selanjutnya ditulis balita). Dengan demikian membandingkan prevalensi dengan standar yang berbeda dapat menyebabkan kesalahan interpretasi. Selain dari perbedaan besaran prevalensi status gizi, penggunaan standar WHO yang baru mempunyai implikasi penggunaan kartu menuju sehat (KMS) yang masih didasarkan atas standar NCHS, buku-buku pedoman dan hal lain yang terkait dengan perubahan tersebut.

Oleh karena itu, para pakar di bidang gizi sepakat untuk mengevaluasi dulu perubahan besaran masalah gizi akibat penerapan standar baru tersebut. Segera sesudah sosialisasi WHO-SEARO tersebut, berbagai pertemuan diselenggarakan oleh pemangku kepentingan (WHO, UNICEF, Depkes, Persagi) dan dihadiri oleh para pakar gizi di beberapa tempat antara lain di Yogyakarta, Makassar, Bogor, danJakarta.

Tujuan tulisan ini adalah untuk mengetahui perbedaan prevalensi balita pendek dan kurus berdasarkan standar NCHS yang digunakan di Indonesia sampai dengan saat ini dan standar baru WHO-GS yang direkomendasikan WHO.

\section{METODE}

Data yang digunakan dalam analisis adalah data sekunder Survei Kesehatan Rumah Tangga (SKRT) tahun 2004. Sebanyak 3316 balita berumur $0-59$ bulan dengan variabel umur anak, berat badan, dan tinggi/panjang badan yang lengkap dimasukkan dalam analisis ini. Dalam tulisan ini tidak dibahas tentang metodologi pengumpulan data SKRT 2004, tetapi lebih terfokus pada perbedaan status gizi karena menggunakan dua standar antropometri yang berbeda. Sebelum analisis data dilakukan, data disusun kembali menurut urutan susunan variabel dari tiap sampel sesuai dengan urutan dalam perangkat lunak yang disusun WHO untuk kepentingan pengolahan data antropometri. Kemudian data disalin ke dalam file perangkat lunak. Analisis dilakukan dengan menghitung zscore untuk indeks antropometri tinggi badan menurut umur (TB/U) dan berat badan menurut tinggi badan (BB/TB) dengan memakai perangkat lunak antropometri yang disusun WHO.

Indeks TB/U dengan z-score <-3.00 SD dikategorikan sebagai balita sangat pendek, $<-2.00$ sampai -3.00 dikategorikan sebagai balita pendek, dan $\geq-2.00$ dikategorikan sebagai normal. Indeks BB/TB dengan zscore <-3.00 SD dikategorikan sebagai balita sangat kurus, <-2.00 sampai -3.00 dikategorikan sebagai balita kurus, dan $\geq-$ 2.00 dikategorikan sebagai normal. Analisis bivariat dilakukan dengan melakukan krostabulasi yang membandingkan besaran prevalensi balita menurut indeks TB/U dengan menggunakan standar antropometri NCHS dibanding WHO. Analisis krostabulasi yang sama juga dilakukan untuk indeks BB/TB. Untuk mengetahui besaran prevalensi status gizi balita yang lebih rinci, analisis juga dilakukan untuk mengetahui perbedaan prevalensi tersebut menurut umur anak, jenis kelamin, dan daerah tempat tinggal.

\section{HASIL}

a. Karakteristik Sampel

Tabel 1 menunjukkan karakteristik sampel balita. Proporsi anak laki-laki dan perempuan seimbang. Demikian pula dengan proporsi anak menurut kelompok umur. Proporsi anak yang tinggal di daerah perkotaan lebih kecil (42,9\%) dibandingkan dengan anak yang tinggal di daerah perdesaan $(57,1 \%)$. 
Tabel 1

Karakteristik Sampel Balita, SKRT 2004

\begin{tabular}{|c|c|c|}
\hline Karakteristik & Jumlah sample (n) & Persen \\
\hline \multicolumn{3}{|l|}{ Jenis kelamin } \\
\hline Laki-laki & 1511 & 48,5 \\
\hline Perempuan & 1605 & 51,5 \\
\hline \multicolumn{3}{|l|}{ Umur (dalam bulan) } \\
\hline $0-5$ & 214 & 6,9 \\
\hline $6-11$ & 261 & 8,4 \\
\hline $12-23$ & 562 & 18,0 \\
\hline $24-35$ & 637 & 20,4 \\
\hline $36-47$ & 714 & 22,9 \\
\hline $48-59$ & 728 & 23,4 \\
\hline \multicolumn{3}{|l|}{ Daerah tempat tinggal } \\
\hline Perkotaan & 1336 & 42,9 \\
\hline Perdesaan & 1780 & 57,1 \\
\hline Jumlah & 3116 & 100 \\
\hline
\end{tabular}

b. Pola Pertumbuhan

Pada Gambar 1 dan 2 terlihat rata-rata tinggi/panjang badan anak dari umur 0 hingga 59 bulan dari SKRT dibandingkan dengan WHO-GS. Gambar 1 memperlihatkan rata-rata tinggi/ panjang badan anak laki-laki yang mengikuti garis median WHO-GS sampai anak berumur berumur 12 bulan, tetapi sesudahnya tidak dapat mengikuti nilai median. Rata-rata tinggi/panjang badan anak laki-laki terus menurun di bawah nilai median, sehingga pada umur 24 bulan dan sesudahnya, nilai rata-rata tinggi badan hanya sedikit di atas $-2,0$ SD dari standar WHO-GS. Pola pertumbuhan tinggi/panjang badan pada anak perempuan juga hampir sama dengan yang terjadi pada anak laki-laki (Gambar 2).

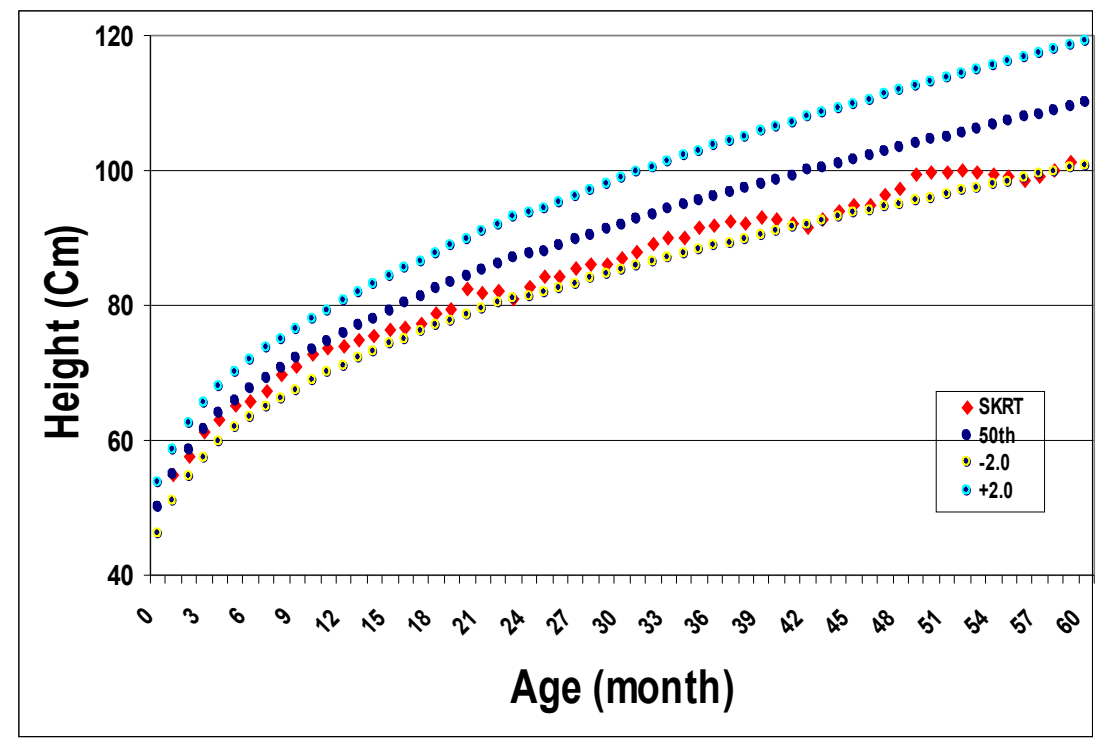

Gambar 1. Rata-rata tinggi/panjang badan menurut umur pada anak laki-laki dibanding standar WHO-GS 


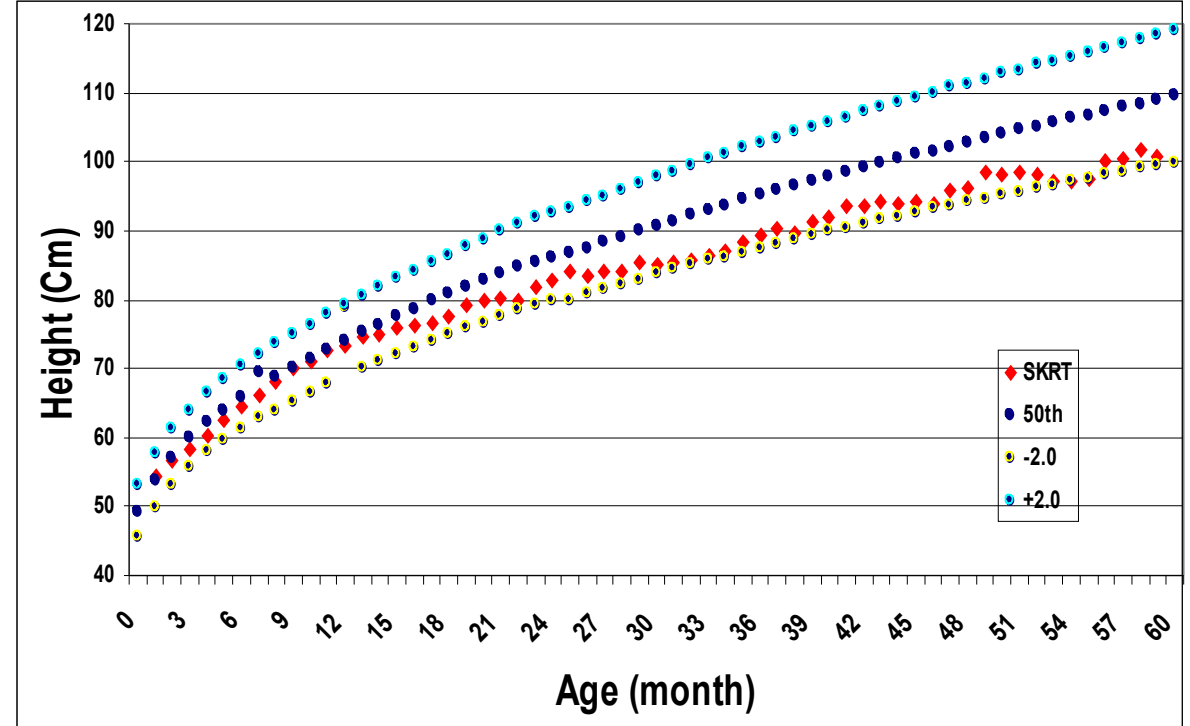

Gambar 2

Rata-rata tinggi/panjang badan menurut umur pada anak perempuan dibanding standar WHO-GS

Pada Gambar 3 terlihat rata-rata berat badan anak laki-laki menurut tinggi badan. Terlihat bahwa rata-rata berat badan anak laki-laki dari berkisar di sekitar nilai median standar WGO-GS. Pada tinggi badan di bawah $85 \mathrm{Cm}$, nilai rata-rata pada nilai median atau sedikit di bawah median, sedangkan pada tinggi badan di atasnya, nilai rata-rata berat badan selalu di bawah nilai median. Pada tinggi badan di atas 110 $\mathrm{Cm}$, jumlah sampel terbatas sehingga ratarata berat badan berfluktuasi. Pola yang sama juga terjadi pada anak perempuan seperti terlihat pada Gambar 4.

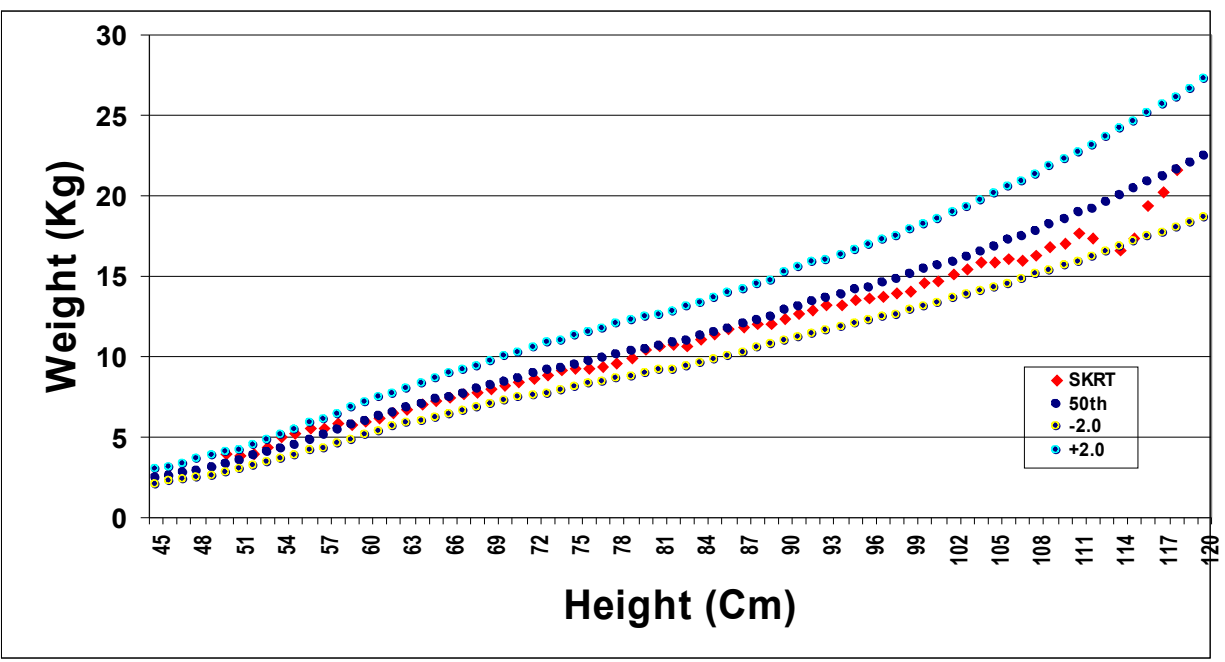

Gambar 3

Rata-rata berat badan menurut tinggi badan pada anak laki-laki dibanding standar WHO-GS 


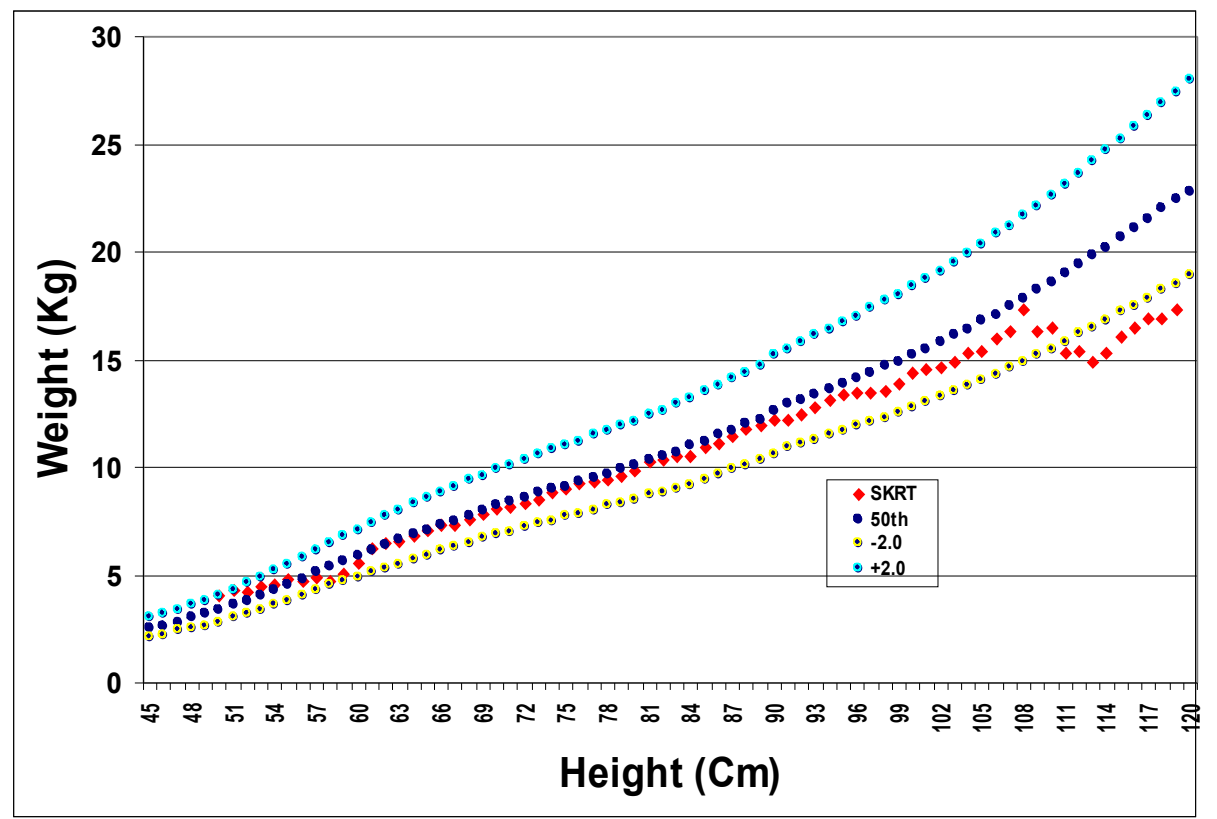

Gambar 4

Rata-rata berat badan menurut tinggi badan pada anak laki-laki dibanding standar WHO-GS

c. Rata-rata z-score BB/TB dan TB/U

Tabel 2 memperlihatkan rata-rata $z-$ score TB/U menurut standar NCHS dan WHO-GS. Terlihat bahwa rata-rata z-score hampir sama menurut standar NCHS maupun WHO-GS, tetapi terlihat bahwa ratarata z-core menurut standar WHO-GS cenderung lebih rendah yang mulai terlihat pada umur di 12 bulan ke atas. Perbedaan tersebut bervariasi menurut umur, artinya tidak ada pola yang selalu sama antar umur. Perbedaan rata-rata z-score antara 0.01 0.46 pada gabungan anak laki-laki dan perempuan.

Tabel 2

Rata-rata z-score TB/U menurut standar NCHS dan WHO-GS

\begin{tabular}{ccccccc}
\hline \multirow{2}{*}{ Umur (bulan) } & \multicolumn{3}{c}{ TB/U Standar NCHS } & \multicolumn{3}{c}{ TB/U Standar WHO-GS } \\
\cline { 2 - 7 } & \multicolumn{1}{c}{ Lk } & Pr & Lk+Pr & \multicolumn{1}{c}{ Lk } & $\operatorname{Pr}$ & Lk+Pr \\
\hline 1 & -0.15 & 1.07 & 0.51 & -0.24 & 1.22 & 0.55 \\
2 & 0.69 & 0.54 & 0.60 & 0.72 & 0.47 & 0.57 \\
3 & -0.08 & -0.68 & -0.31 & -0.24 & -0.91 & -0.50 \\
4 & 0.53 & -0.59 & 0.08 & 0.58 & -0.76 & 0.04 \\
5 & -0.48 & -0.24 & -0.39 & -0.60 & -0.25 & -0.47 \\
6 & -0.48 & -0.25 & -0.34 & -0.52 & -0.21 & -0.33 \\
7 & -0.76 & -0.65 & -0.70 & -0.78 & -0.62 & -0.69 \\
8 & -0.94 & -0.46 & -0.65 & -0.97 & -0.40 & -0.63 \\
9 & 0.33 & 0.24 & 0.27 & 0.55 & 0.40 & 0.46 \\
10 & -0.88 & -0.15 & -0.55 & -0.86 & -0.04 & -0.49 \\
11 & -0.33 & -0.78 & -0.57 & -0.23 & -0.76 & -0.51
\end{tabular}


Gizi Indon 2008, 31(1):9-22

Sandjaja
Kajian perbedaan prevalensi balita kurus

\begin{tabular}{|c|c|c|c|c|c|c|}
\hline 12 & -0.31 & 0.48 & 0.06 & -0.20 & 0.64 & 0.19 \\
\hline 13 & -1.62 & -0.69 & -1.19 & -1.70 & -0.66 & -1.22 \\
\hline 14 & -0.54 & -0.53 & -0.53 & -0.48 & -0.47 & -0.47 \\
\hline 15 & -1.05 & -0.61 & -0.77 & -1.08 & -0.56 & -0.75 \\
\hline 16 & -1.64 & -0.68 & -1.13 & -1.75 & -0.63 & -1.16 \\
\hline 17 & -1.33 & -1.20 & -1.27 & -1.42 & -1.19 & -1.31 \\
\hline 18 & -1.17 & -1.29 & -1.22 & -1.26 & -1.29 & -1.27 \\
\hline 19 & -1.08 & -0.74 & -0.93 & -1.18 & -0.71 & -0.97 \\
\hline 20 & -1.56 & -0.51 & -1.07 & -1.74 & -0.48 & -1.16 \\
\hline 21 & 0.85 & -1.50 & -0.16 & 0.95 & -1.51 & -0.10 \\
\hline 22 & -2.42 & -1.25 & -1.85 & -2.73 & -1.26 & -2.01 \\
\hline 23 & -2.03 & -1.68 & -1.86 & -2.30 & -1.69 & -2.00 \\
\hline 24 & -0.16 & 0.07 & -0.05 & -0.67 & -0.31 & -0.49 \\
\hline 25 & -1.12 & -0.56 & -0.85 & -1.66 & -0.93 & -1.31 \\
\hline 26 & -0.86 & -0.73 & -0.79 & -1.38 & -1.09 & -1.22 \\
\hline 27 & -0.76 & -1.27 & -0.99 & -1.27 & -1.63 & -1.43 \\
\hline 28 & -0.71 & -0.54 & -0.66 & -1.21 & -0.90 & -1.12 \\
\hline 29 & -0.90 & -1.39 & -1.13 & -1.39 & -1.74 & -1.55 \\
\hline 30 & -1.36 & -0.85 & -1.10 & -1.85 & -1.18 & -1.50 \\
\hline 31 & -0.72 & -1.52 & -1.07 & -1.17 & -1.85 & -1.46 \\
\hline 32 & -0.67 & -1.65 & -0.96 & -1.10 & -1.95 & -1.35 \\
\hline 33 & -0.97 & -1.30 & -1.12 & -1.38 & -1.60 & -1.48 \\
\hline 34 & -0.60 & -1.63 & -0.97 & -0.98 & -1.91 & -1.31 \\
\hline 35 & -1.21 & -1.57 & -1.40 & -1.58 & -1.84 & -1.72 \\
\hline 36 & -0.43 & -0.67 & -0.54 & -0.76 & -0.96 & -0.85 \\
\hline 37 & -0.79 & -1.35 & -1.03 & -1.10 & -1.61 & -1.32 \\
\hline 38 & -1.32 & 0.92 & -0.51 & -1.63 & 0.60 & -0.82 \\
\hline 39 & -1.06 & -1.74 & -1.27 & -1.34 & -1.97 & -1.53 \\
\hline 40 & -0.63 & -0.52 & -0.56 & -0.88 & -0.79 & -0.82 \\
\hline 41 & -2.08 & -1.36 & -1.68 & -2.35 & -1.58 & -1.92 \\
\hline 42 & -1.96 & -1.10 & -1.57 & -2.19 & -1.32 & -1.81 \\
\hline 43 & -1.60 & -0.96 & -1.28 & -1.80 & -1.19 & -1.50 \\
\hline 44 & -1.55 & -1.22 & -1.42 & -1.74 & -1.43 & -1.62 \\
\hline 45 & -1.47 & -1.87 & -1.56 & -1.64 & -2.04 & -1.73 \\
\hline 46 & -1.40 & -1.14 & -1.26 & -1.54 & -1.34 & -1.43 \\
\hline 47 & -2.01 & -2.00 & -2.01 & -2.15 & -2.14 & -2.15 \\
\hline 48 & -0.74 & -0.82 & -0.78 & -0.84 & -1.02 & -0.94 \\
\hline 49 & -1.25 & -1.12 & -1.17 & -1.34 & -1.30 & -1.32 \\
\hline 50 & -0.93 & -0.93 & -0.93 & -1.01 & -1.12 & -1.06 \\
\hline 51 & -0.84 & -1.33 & -1.08 & -0.90 & -1.49 & -1.18 \\
\hline 52 & -1.79 & -1.31 & -1.51 & -1.85 & -1.47 & -1.63 \\
\hline 53 & -1.10 & -1.53 & -1.37 & -1.15 & -1.66 & -1.47 \\
\hline 54 & -1.45 & -2.41 & -1.82 & -1.49 & -2.48 & -1.87 \\
\hline 55 & -2.26 & -1.67 & -2.03 & -2.29 & -1.79 & -2.09 \\
\hline 56 & -1.65 & -1.72 & -1.69 & -1.67 & -1.83 & -1.77 \\
\hline 57 & -2.23 & -0.84 & -1.44 & -2.24 & -1.01 & -1.54 \\
\hline 58 & -2.22 & -1.76 & -1.87 & -2.22 & -1.86 & -1.94 \\
\hline 59 & -1.30 & -1.31 & -1.30 & -1.30 & -1.44 & -1.36 \\
\hline
\end{tabular}

Bila dilihat menurut jenis kelamin, pola yang sama juga terlihat antara perbedaan
TB/U menurut standar NCHS dan WHO-GS, tidak banyak perbedaaan pada umur di 
bawah 12 bulan, tetapi ada kecenderungan z-score lebih rendah menurut WHO-GS pada umur 12 bulan ke atas. Perbedaan antara standar TB/U antar dua standar tersebut bervariasi antara $0.02-0.54$ pada anak lakilaki dan $0-0.37$ pada anak perempuan.

Tabel 3 memperlihatkan rata-rata zscore BB/TB menurut standar NCHS dan WHO-GS. Terlihat bahwa pada umur di bawah 12 bulan rata-rata z-score lebih rendah bila menggunakan standar WHO-GS dibanding NCHS, sedangkan pada umur 12 bulan atau lebih tidak terdapat pola yang jelas, sebagian lebih tinggi dan sebagian lebih rendah. Perbedaan tersebut bervariasi menurut umur, artinya tidak ada pola yang selalu sama antar umur. Perbedaan rata-rata z-score antara 0.01 - 0.52 pada gabungan anak laki-laki dan perempuan.

Tabel 3

Rata-rata z-score BB/TB menurut standar NCHS dan WHO-GS

\begin{tabular}{|c|c|c|c|c|c|c|}
\hline \multirow{2}{*}{ Umur (bulan) } & \multicolumn{3}{|c|}{ BB/TB Standar NCHS } & \multicolumn{3}{|c|}{ BB/TB Standar WHO-GS } \\
\hline & Lk & $\operatorname{Pr}$ & $\mathrm{Lk}+\mathrm{Pr}$ & Lk & $\operatorname{Pr}$ & $L k+P r$ \\
\hline 1 & 0.37 & -0.32 & 0.00 & 0.11 & -1.06 & -0.52 \\
\hline 2 & 0.06 & 0.14 & 0.11 & -0.42 & -0.41 & -0.41 \\
\hline 3 & -0.04 & 1.10 & 0.39 & -0.51 & 0.81 & -0.01 \\
\hline 4 & -0.54 & 0.21 & -0.24 & -0.94 & -0.23 & -0.65 \\
\hline 5 & 0.15 & -0.09 & 0.06 & -0.07 & -0.46 & -0.21 \\
\hline 6 & 0.56 & 0.24 & 0.36 & 0.61 & 0.02 & 0.25 \\
\hline 7 & 0.14 & 0.30 & 0.23 & 0.03 & 0.14 & 0.09 \\
\hline 8 & -0.50 & -0.98 & -0.79 & -0.62 & -1.17 & -0.95 \\
\hline 9 & -1.23 & -0.38 & -0.68 & -1.13 & -0.27 & -0.58 \\
\hline 10 & -0.51 & -1.19 & -0.82 & -0.40 & -1.13 & -0.73 \\
\hline 11 & -0.85 & -0.17 & -0.49 & -0.73 & -0.02 & -0.36 \\
\hline 12 & -0.49 & -0.84 & -0.65 & -0.25 & -0.55 & -0.39 \\
\hline 13 & -0.81 & -0.62 & -0.72 & -0.61 & -0.38 & -0.50 \\
\hline 14 & -0.95 & -0.78 & -0.84 & -0.64 & -0.57 & -0.59 \\
\hline 15 & -1.08 & -0.44 & -0.67 & -0.74 & -0.08 & -0.31 \\
\hline 16 & -0.77 & -0.68 & -0.72 & -0.46 & -0.35 & -0.41 \\
\hline 17 & -1.72 & -0.85 & -1.33 & -1.44 & -0.48 & -1.01 \\
\hline 18 & -0.80 & -1.14 & -0.95 & -0.47 & -0.88 & -0.65 \\
\hline 19 & -0.87 & -1.06 & -0.96 & -0.54 & -0.66 & -0.59 \\
\hline 20 & -1.63 & -1.25 & -1.45 & -1.28 & -0.91 & -1.11 \\
\hline 21 & -2.15 & -1.55 & -1.89 & -1.90 & -1.08 & -1.55 \\
\hline 22 & -0.25 & -1.46 & -0.84 & 0.04 & -1.14 & -0.54 \\
\hline 23 & -1.24 & -0.70 & -0.98 & -0.96 & -0.32 & -0.65 \\
\hline 24 & -0.94 & -0.84 & -0.89 & -0.75 & -0.58 & -0.66 \\
\hline 25 & -0.27 & -0.40 & -0.34 & 0.12 & 0.00 & 0.06 \\
\hline 26 & -0.30 & -1.22 & -0.81 & 0.06 & -0.99 & -0.51 \\
\hline 27 & -0.92 & -0.59 & -0.77 & -0.72 & -0.18 & -0.48 \\
\hline 28 & -0.45 & -1.56 & -0.75 & -0.14 & -1.44 & -0.49 \\
\hline 29 & -1.19 & -0.73 & -0.98 & -1.04 & -0.35 & -0.72 \\
\hline 30 & -0.83 & -1.09 & -0.96 & -0.58 & -0.85 & -0.71 \\
\hline 31 & -0.25 & -0.95 & -0.55 & 0.13 & -0.66 & -0.21 \\
\hline 32 & -1.12 & -1.07 & -1.10 & -0.98 & -0.75 & -0.92 \\
\hline 33 & -0.07 & -1.46 & -0.68 & 0.27 & -1.26 & -0.40 \\
\hline 34 & -0.52 & -0.99 & -0.69 & -0.25 & -0.76 & -0.43 \\
\hline
\end{tabular}


Gizi Indon 2008, 31(1):9-22

Sandjaja

\begin{tabular}{lllllll}
35 & -0.38 & -0.32 & -0.35 & -0.01 & 0.04 & 0.02 \\
36 & -0.96 & -0.66 & -0.82 & -0.81 & -0.47 & -0.66 \\
37 & -0.82 & -0.19 & -0.54 & -0.63 & 0.09 & -0.32 \\
38 & -0.95 & -1.49 & -1.15 & -0.79 & -1.62 & -1.09 \\
39 & -0.77 & -0.78 & -0.77 & -0.54 & -0.69 & -0.58 \\
40 & -0.12 & -0.76 & -0.51 & 0.14 & -0.64 & -0.34 \\
41 & -0.00 & -1.14 & -0.63 & 0.40 & -1.04 & -0.40 \\
42 & -0.42 & -0.77 & -0.58 & -0.13 & -0.67 & -0.37 \\
43 & -0.65 & -0.45 & -0.55 & -0.40 & -0.32 & -0.36 \\
44 & -0.55 & -1.58 & -0.96 & -0.38 & -1.58 & -0.85 \\
45 & -0.80 & -0.80 & -0.80 & -0.61 & -0.64 & -0.62 \\
46 & -1.18 & -1.25 & -1.22 & -1.05 & -1.24 & -1.15 \\
47 & -0.31 & -0.68 & -0.46 & -0.08 & -0.54 & -0.26 \\
48 & -0.72 & -0.68 & -0.70 & -0.57 & -0.63 & -0.60 \\
49 & -0.57 & -0.92 & -0.80 & -0.41 & -0.89 & -0.72 \\
50 & -0.79 & -0.63 & -0.71 & -0.63 & -0.60 & -0.61 \\
51 & -0.49 & -0.77 & -0.63 & -0.35 & -0.75 & -0.55 \\
52 & -1.23 & -1.03 & -1.11 & -1.14 & -0.97 & -1.04 \\
53 & -0.55 & -0.48 & -0.51 & -0.43 & -0.38 & -0.40 \\
54 & -0.70 & -0.67 & -0.69 & -0.53 & -0.53 & -0.53 \\
55 & -0.18 & -0.38 & -0.26 & -0.03 & -0.26 & -0.12 \\
56 & -1.14 & -0.53 & -0.77 & -1.05 & -0.45 & -0.69 \\
57 & -0.80 & -1.09 & -0.97 & -0.62 & -1.14 & -0.92 \\
58 & -1.05 & -0.92 & -0.95 & -0.90 & -0.90 & -0.90 \\
59 & -0.98 & -0.89 & -0.94 & -0.92 & -0.95 & -0.93 \\
\hline
\end{tabular}

Bila dilihat menurut jenis kelamin, pola yang sama juga terlihat antara perbedaan $\mathrm{BB} / \mathrm{TB}$ menurut standar NCHS dan WHOGS, perbedaaan pada umur di bawah 12 bulan lebih tinggi dibanding pada umur 12 bulan atau lebih. Perbedaan antara standar $\mathrm{BB} / \mathrm{TB}$ antar dua standar tersebut bervariasi antara $0.05-0.47$ pada anak laki-laki dan 0 -0.74 pada anak perempuan.

d. Prevalensi balita pendek dan sangat pendek
Prevalensi balita pendek dan sangat pendek menurut indeks tinggi badan menurut umur (TB/U) yang dianalisis dengan standar NCHS dan WHO-GS terlihat pada Tabel 4. Secara keseluruhan prevalensi balita sangat pendek menurut standar NCHS dan WHOGS masing-masing sebesar 9,4 dan 12,0 persen, sedangkan prevalensi balita pendek masing-masing sebesar 14,7 dan 16,6 persen. Dengan demikian terlihat bahwa dengan menggunakan standar WHO-GS, prevalensi balita pendek dan sangat pendek lebih tinggi 1,9-2,6 persen dibandingkan prevalensi jika menggunakan standar NCHS. 
Tabel 4

Prevalensi status gizi menurut indeks TB/U menurut Standar NCHS dan WHO-GS

\begin{tabular}{|c|c|c|c|c|c|c|c|}
\hline \multirow[t]{2}{*}{ Karakteristik } & \multirow[t]{2}{*}{$\mathrm{n}$} & \multicolumn{3}{|c|}{$\begin{array}{c}\text { Prevalensi menurut standar } \\
\text { NCHS }\end{array}$} & \multicolumn{3}{|c|}{$\begin{array}{c}\text { Prevalensi menurut standar } \\
\text { WHO-GS }\end{array}$} \\
\hline & & S.pendek & Pendek & Normal & S.pendek & Pendek & Normal \\
\hline \multicolumn{8}{|l|}{ Jenis kelamin } \\
\hline Laki-laki & 1511 & 9,9 & 15,4 & 74,7 & 13,3 & 16,5 & 70,2 \\
\hline Perempuan & 1605 & 8,7 & 14,0 & 77,3 & 10,7 & 16,7 & 72,6 \\
\hline \multicolumn{8}{|l|}{ Umur (bulan) } \\
\hline $0-5$ & 214 & 5,1 & 6,1 & 88,8 & 7,9 & 8,4 & 83,7 \\
\hline $6-11$ & 261 & 7,3 & 14,5 & 78,2 & 10,7 & 14,2 & 75,1 \\
\hline $12-23$ & 562 & 11,4 & 15,9 & 72,7 & 14.7 & 15,0 & 70,3 \\
\hline $24-35$ & 637 & 10,8 & 14,9 & 74,3 & 16,2 & 18,7 & 65,1 \\
\hline $36-47$ & 714 & 8,8 & 15,0 & 76,2 & 10,5 & 19,4 & 70,1 \\
\hline $48-59$ & 728 & 9,1 & 15,6 & 75,3 & 9,5 & 15,5 & 74,0 \\
\hline \multicolumn{8}{|l|}{ Tempat tinggal } \\
\hline Perkotaan & 1336 & 6,7 & 14,3 & 79,0 & 9,3 & 16,5 & 74,2 \\
\hline Perdesaan & 1780 & 11,2 & 15,0 & 73,8 & 14,0 & 16,7 & 69,3 \\
\hline Jumlah & 3116 & 9,4 & 14,7 & 75,9 & 12,0 & 16,6 & 71,4 \\
\hline
\end{tabular}

Catatan: S.pendek: Sangat pendek

Prevalensi balita pendek dan sangat pendek pada anak laki-laki sedikit lebih tinggi (25,3\% NCHS, $29,8 \%$ WHO-GS) dibandingkan anak perempuan $(22,7 \%$ NCHS, 27,4\% WHO-GS). Dengan demikian analisis dengan standar NCHS dan WHOGS memperlihatkan perbedaan prevalensi balita pendek dan sangat pendek lebih tinggi antara 4,5 - 4,7 persen dengan menggunakan standar WHO-GS.

Prevalensi balita pendek dan sangat pendek menurut daerah tempat tinggal menunjukkan hal yang sama, yaitu prevalensi dengan menggunakan standar WHO-GS lebih tinggi dibanding standar NCHS. Balita pendek dan sangat pendek lebih tinggi pada balita di daerah perdesaan (26,2\% NCHS dan 30,7\% WHO-GS) dibanding balita dari daerah perkotaan (21,0\% NCHS dan 25,8\% WHO-GS). Analisis dengan standar NCHS dan WHOGS juga memperlihatkan prevalensi balita pendek dan sangat pendek lebih tinggi dengan menggunakan standar WHO-GS dengan perbedaan prevalensi antara 4,5 4,8 persen.

Prevalensi balita pendek dan sangat pendek menurut kelompok umur menunjukkan bahwa prevalensi dengan menggunakan standar WHO-GS selalu konsisten lebih tinggi dibanding menggunakan standar NCHS. Tingkat perbedaan prevalensi balita pendek dan sangat pendek dengan menggunakan standar NCHS dan WHO-GS berkisar antara terendah 1,3 persen pada kelompok umur 48-59 bulan sampai dengan tertinggi 9,2 persen pada kelompok umur 24-35 bulan. Prevalensi balita pendek dan sangat pendek menurut umur juga memperlihatkan semakin balita bertambah umur, semakin tinggi prevalensinya. Prevalensi pendek dan sangat pendek pada umur 0-5 bulan sudah di atas 10 persen (12,2\% NCHS dan 16,3\% WHO-GS) dan 34,9 persen pada umur 24-35 bulan.

e. Prevalensi balita kurus dan sangat
kurus
Prevalensi balita kurus dan sangat kurus menurut indeks berat badan menurut tinggi badan (BB/TB) yang dianalisis dengan standar NCHS dan WHO-GS terlihat pada Tabel 5. Secara keseluruhan prevalensi balita sangat kurus menurut standar NCHS dan WHO-GS masing-masing sebesar 3,9 
dan 5,9 persen, sedangkan prevalensi balita kurus masing-masing sebesar 9,9 dan 9,2 persen. Dengan demikian terlihat bahwa dengan menggunakan standar WHO-GS, prevalensi balita sangat kurus lebih tinggi 2,0 persen disbanding menggunakan standar
NCHS, sedangkan prevalensi balita kurus lebih tinggi 0,7 persen. Bila prevalensi sangat kurus dan kurus digabung, perbedaan prevalensi lebih tinggi 1,3 persen jika menggunakan standar WHO-GS dibanding standar NCHS.

Tabel 5

Prevalensi status gizi menurut indeks BB/TB menurut Standar NCHS dan WHO-GS

\begin{tabular}{|c|c|c|c|c|c|c|c|}
\hline \multirow[t]{2}{*}{ Karakteristik } & \multirow[t]{2}{*}{$\mathrm{n}$} & \multicolumn{3}{|c|}{$\begin{array}{c}\text { Prevalensi menurut standar } \\
\text { NCHS }\end{array}$} & \multicolumn{3}{|c|}{$\begin{array}{c}\text { Prevalensi menurut standar } \\
\text { WHO-GS }\end{array}$} \\
\hline & & S.kurus & Kurus & Normal & S.kurus & Kurus & Norma \\
\hline \multicolumn{8}{|l|}{ Jenis kelamin } \\
\hline Laki-laki & 1511 & 3,5 & 10,1 & 86,4 & 5,8 & 9,9 & 84,3 \\
\hline Perempuan & 1605 & 4,2 & 9,5 & 86,3 & 5,9 & 14,5 & 85,5 \\
\hline \multicolumn{8}{|l|}{ Umur (bulan) } \\
\hline $0-5$ & 214 & 0,9 & 4,7 & 94,4 & 9,8 & 11,2 & 79,0 \\
\hline $6-11$ & 261 & 5,4 & 12,7 & 81,9 & 6,5 & 13,0 & 80,5 \\
\hline $12-23$ & 562 & 6,9 & 11,2 & 81,9 & 6,7 & 8,6 & 84,7 \\
\hline $24-35$ & 637 & 3,8 & 9,2 & 87,0 & 6,0 & 7,7 & 86,3 \\
\hline $36-47$ & 714 & 4,2 & 11,5 & 84,3 & 6,7 & 9,7 & 83,6 \\
\hline $48-59$ & 728 & 1,7 & 8,2 & 90,1 & 2,9 & 8,7 & 88,4 \\
\hline \multicolumn{8}{|l|}{ Tempat tinggal } \\
\hline Perkotaan & 1336 & 3,1 & 9,4 & 87,5 & 5,0 & 8,6 & 86,4 \\
\hline Perdesaan & 1780 & 4,4 & 10,2 & 85,4 & 6,5 & 9,7 & 83,8 \\
\hline Jumlah & 3116 & 3,9 & 9,9 & 86,2 & 5,9 & 9,2 & 84,9 \\
\hline
\end{tabular}

Catatan: S.kurus : Sangat kurus

Prevalensi balita kurus dan sangat kurus pada anak laki-laki hampir sama dengan menggunakan standar NCHS $(13,7 \%)$ dibanding dengan standar WHO-GS $(13,6 \%)$, tetapi lebih tinggi pada anak perempuan jika menggunakan standar WHO-GS $(20,4 \%)$ dibanding standar NCHS $(15,7 \%)$. Dengan demikian analisis dengan standar NCHS dan WHO-GS memperlihatkan perbedaan prevalensi balita kurus dan sangat kurus antara 0,1 - 4,7 persen menurut jenis kelamin.

Prevalensi balita kurus dan sangat kurus menurut daerah tempat tinggal menunjukkan hal yang sama, yaitu prevalensi dengan menggunakan standar WHO-GS lebih tinggi dibanding standar
NCHS. Balita kurus dan sangat kurus lebih tinggi pada balita di daerah perdesaan $(14,6 \%$ NCHS dan 16,2\% WHO-GS) dibanding balita dari daerah perkotaan $(12,5 \%$ NCHS dan 13,6\% WHO-GS). Dengan demikian analisis dengan standar NCHS dan WHO-GS memperlihatkan perbedaan prevalensi balita kurus dan sangat kurus lebih tinggi dengan menggunakan standar WHO-GS dengan perbedaan antara 1,1-1,6 persen.

Prevalensi balita kurus dan sangat kurus menurut kelompok umur menunjukkan bahwa prevalensi dengan menggunakan standar WHO-GS selalu konsisten lebih tinggi dibanding menggunakan standar NCHS. Tingkat perbedaan prevalensi balita 
kurus dan sangat kurus dengan menggunakan standar NCHS dan WHO-GS sangat tajam berkisar antara terendah 0,7 persen pada kelompok umur 24-47 bulan sampai dengan tertinggi 15,4 persen pada kelompok umur $0-5$ bulan.

\section{BAHASAN}

WHO-SEARO melakukan sosialisasi standar antropometri baru (WHO-GS) di Bangkok pada 4-7 Juni 2006 untuk perencana program gizi, cendekiawan, dan pengguna standar anthropometri di Asia Tenggara. Dalam sosialisasi ini WHO mendorong negara-negara di Asia Tenggara untuk menggunakan WHO-GS karena beberapa alasan yaitu standar tersebut disusun atas dasar hasil studi multisenter di Brazil, India, Norwegia, Oman dan Amerika Serikat (USA) $)^{11}$, lebih baik dari standar yang digunakan sekarang oleh beberapa negara yaitu NCHS yang hanya didasarkan pada satu kelompok masyarakat di USA, sampel adalah bayi dan anak balita yang lahir dari keluarga mampu, di lingkungan yang mendukung pencapaian pertumbuhan potensial, ibu berpendidikan minimal SLTA dan tidak merokok, standar tersebut didasarkan pada sampel yang mendapat air susu ibu (ASI) eksklusif. Jadi adopsi standar baru juga bersamaan dengan penekanan pelaksanaan ASI eksklusif'.

Penggunaan standar antropometri anak balita di Indonesia sejak tahun 1976 sampai dengan tahun 1980-an adalah standar Harvard, dan kemudian dilanjutkan dengan menggunakan standar NCHS sampai dengan saat ini. NCHS dianjurkan WHO karena dianggap memenuhi hampir semua persyaratan untuk menjadi populasi acuan². Pada saat itu penggantian standar dari Harvard ke NCHS tidak begitu dipermasalahkan dan pelaksana program di lapangan tidak menyadari adanya perubahan tersebut, hanya mengenali bahwa KMS dengan standar NCHS kurvanya berbeda. Namun dengan semakin berkembangnya ilmu pengetahuan dan semakin kritisnya masyarakat, ditambah lagi maraknya gizi buruk, maka penggantian kembali standar
NCHS menjadi standar WHO-GS harus disiapkan dengan baik, agar tidak terjadi gejolak pada pelaksana program ${ }^{3}$.

Hasil analisis anak balita pendek dalam tulisan ini menunjukkan bahwa dengan menggunakan standar WHO-GS, rata-rata zscore cenderung lebih rendah yang mulai terlihat pada umur di 12 bulan ke atas. Dengan demikian prevalensi balita pendek dan sangat pendek selalu lebih tinggi antara 1,3 sampai 9,2 persen dibanding menggunakan standar NCHS. Analisis juga mendapatkan bahwa prevalensi anak balita pendek meningkat tajam dengan bertambahnya umur anak balita. Hal tersebut menunjukkan potensi tumbuh anak balita Indonesia masih belum optimal dengan pencapaian panjang atau tinggi badan sangat rendah. Selain itu komposisi umur balita akan mempengaruhi prevalensi anak balita pendek. Bila sampel balita tidak proporsional menurut kelompok umur akan berpengaruh terhadap besarnya prevalensi ${ }^{4}$ karena perbedaan prevalensi balita pendek antar kelompok umur. Prevalensi balita sangat pendek dan pendek tidak banyak berbeda menurut jenis kelamin, tetapi lebih terlihat menurut daerah tempat tinggal. Prevalensi balita pendek dan sangat pendek yang tinggal di perdesaan lebih tinggi dibanding di perkotaan. Dengan demikian faktor-faktor penghambat pertumbuhan balita di perdesaan perlu mendapat perhatian yang lebih baik.

Perbedaan prevalensi balita pendek yang lebih tinggi dengan menggunakan standar WHO-GS tersebut serupa dengan analisis yang dilakukan di Peru, India dan Vietnam yang mendapatkan prevalensi balita pendek yang konsisten selalu lebih tinggi bila penggunakan standar WHO-GS yang baru ${ }^{5}$. Studi di Gabon ${ }^{6}$, Bangladesh, Republik Dominika, Amerika Utara dan negara-negara di Eropa Utara ${ }^{7}$, Malawi ${ }^{8}$ juga mendapatkan hasil prevalensi pendek yang lebih tinggi pada anak umur 3 - 15 bulan. Sumarno (2006) juga mendapatkan prevalensi balita pendek dan sangat pendek (TB/U), serta balita kurus dan sangat kurus (BB/TB) yang selalu konsisten lebih tinggi dengan menggunakan standar WHO-GS dibanding 
NCHS, sedangkan untuk balita kurang berat $(\mathrm{BB} / \mathrm{U})$ prevalensinya lebih rendah bila menggunakan standar WHO-GS dibanding standar NCHS kecuali pada umur 0-5 bulan".

Hasil analisis balita kurus dan sangat kurus menunjukkan rata-rata z-score lebih rendah dengan menggunakan standar WHOGS pada umur di bawah 12 bulan, tetapi tidak ada pola yang khas pada umur di atasnya. Dengan demikian perbedaan prevalensi balita kurus dan sangat kurus lebih tinggi pada umur muda yaitu mencapai 15,4 persen pada umur 0 - 5 bulan $(21,0 \%$ dengan WHO-GS dan $5,6 \%$ dengan NCHS), atau hampir empat kali lipat. Sedangkan pada umur di atas 12 bulan hanya antara 0,7 - 2,8 persen. Bila hanya balita sangat kurus yang dilihat, perbedaan tersebut lebih tinggi lagi yaitu 10 kali lipat pada umur 0 - 5 bulan $(9,8 \%$ menurut WHO-GS dan $0,9 \%$ menurut $\mathrm{NCHS}$ ), tetapi pada umur di atasnya terdapat perbedaan antara 1,2 - 1,7 kali. Secara total perbedaan prevalensi balita kurus dan sangat kurus lebih tinggi 1,3 persen dengan WHO-GS. Perbedaan prevalensi juga terlihat menurut jenis kelamin yang lebih tinggi prevalensi balita kurus pada anak perempuan dan juga menurut daerah tempat tinggal yang lebih tinggi di perdesaan.

Penggunaan standar WHO-GS di negara lain menunjukkan variasi antar negara. Penny (2008) mendapatkan prevalensi balita kurus yang lebih tinggi di India dan Peru tetapi lebih rendah di Vietnam dengan standar WHO-GS ${ }^{5}$. Di Bangladesh, Dominika, Amerika Utara dan negara-negara Eropa Utara, de Onis (2006) juga mendapatkan prevalensi kurus dan sangat kurus pada anak $0-5$ bulan yang jauh lebih tinggi, tetapi berbeda 1,5 - 2,5 kali pada umur di atasnya ${ }^{7}$. Di Malawi terdapat perbedaan prevalensi kurus dan sangat kurus 8,5 kali pada umur $0-5$ bulan bila menggunakan standar WHO-GS dan tidak ada perbedaan pada umur sekitar 12 bulan ${ }^{8}$. Di Nigeria, prevalensi balita sangat kurus juga delapan kali lebih tinggi dengan menggunakan standar WHO-GS ${ }^{9}$.

Dengan melihat perbedaan prevalensi balita kurus dan sangat kurus terutama pada umur di bawah 12 bulan, mempunyai implikasi dalam program penanggulangan gizi buruk pada balita. Dengan menggunakan standar WHO-GS akan lebih baik dalam pemantauan pertumbuhan balita yang sangat cepat terutama pada anak umur di bawah 12 bulan sehingga penyimpangan pertumbuhan dapat dikoreksi lebih dini. Keberhasilan pemberian ASI eksklusif dan makanan pendamping ASI juga dapat dideteksi lebih dini dan upaya penanggulangan dapat dilakukan lebih dini.

Implikasi yang lain adalah dalam pelayanan kesehatan untuk balita gizi buruk. Program gizi di Indonesia merujuk ke rumah sakit balita gizi buruk yang didasarkan pada indeks BB/TB. Balita di bawah garis merah pada KMS menurut $\mathrm{BB} / \mathrm{U}$ perlu dikonfirmasi oleh Puskesmas untuk rujukan ke rumah sakit. Bila BB/TB kurang dari -3.0 SD dan mempunyai tanda-tanda klinis gizi buruk perlu dirujuk ke rumah sakit. Apabila standar WHO diterapkan, akan lebih banyak balita, terutama umur 0 - 5 bulan, yang dirujuk ke rumah sakit karena sangat kurus. Oleh karena itu kemampuan rumah sakit dalam penanganan balita gizi buruk perlu ditingkatkan karena jumlah kasus gizi buruk jauh lebih tinggi (antara 1,2 - 4 kali lipat) dengan menggunakan standar WHO-GS.

Isanaka (2008) melakukan kajian penggunaan standar WHO-GS dalam program gizi di Nigeria untuk balita kurang gizi akut/ sangat kurus ${ }^{10}$. Yang dianalisis adalah kenaikan berat badan, jangka waktu perawatan, angka kematian, kepatuhan dan follow-up, kebutuhan rawat inap dengan menggunakan dua standar NCHS $<>70 \%$ nilai median) dan WHO-GS (z-score < -3.00). Dengan standar WHO-GS prevalensi balita sangat kurus delapan kali lebih banyak, lama perawatan lebih pendek, perbaikan gizi lebih baik, angka kematian lebih sedikit, kepatuhan dan follow-up yang lebih baik, serta kebutuhan rawat inap yang lebih sedikit. Hal tersebut bukan karena dampak dari perawatan, tetapi lebih disebabkan karena kriteria inklusi untuk pelayanan kesehatan pada anak yang lebih muda dimana mempunyai indeks BB/TB yang lebih tinggi dibanding jika menggunakan standar NCHS, anak lebih sedikit yang menderita 
komplikasi karena indeks BB/TB yang lebih tinggi. Hal tersebut berperan pada proporsi anak yang membutuhkan rawat inap lebih sedikit, waktu rawat inap lebih pendek, dan kematian yang lebih sedikit.

Dengan demikian implikasi penggunaan standar WHO-GS mempunyai dimensi yang lebih luas dari sekedar perbedaan prevalensi balita pendek/ sangat pendek dan balita kurus/ sangat kurus, tetapi juga mempunyai implikasi pada program pelayanan kesehatan anak balita yang menderita gizi buruk.

\section{KESIMPULAN}

1. Dengan menggunakan standar WHOGS, rata-rata z-score TB/U cenderung lebih rendah dibanding standar NCHS yang mulai terlihat pada umur di 12 bulan ke atas, tetapi sebaliknya ratarata z-score BB/TB lebih rendah dibanding standar NCHS pada umur di bawah 12 bulan.

2. Dengan menggunakan standar $\mathrm{WHO}$ GS, menjadikan prevalensi balita pendek dan sangat pendek, serta balita kurus dan sangat kurus lebih tinggi dibanding standar NCHS. Perbedaan prevalensi tersebut bervariasi menurut kelompok umur.

3. Implikasi penggunaan standar WHO-GS terhadap status gizi bukan hanya membuat perbedaan dalam prevalensi balita pendek dan kurus saja tetapi juga bisa berdampak kepada pelayanan program gizi untuk balita gizi buruk.

\section{RUJUKAN}

1. Sumarno, Iman, Sosialisasi hasil workshop on New WHO Anthropometric standar in Bangkok 5-7 Juni 2006. Makalah disajikan dalam temu pakar Gizi. Yogyakarta 14-15 July, 2006.

2. Gibson RS. Principle of Nutritional Assessment. Oxford University Press 1990: 209-246.

3. Sumarno, Iman. Petumbuhan bayi menurut ASI di daerah pertanian padi
Gegesik Cirebon dan non pertanian Cibadak Sukabumi. Makalah disajikan pada Workshop Anthropometri di Makasar, September 2006.

4. Sandjaja dan Sihadi. Standarisasi penghitungan prevalensi status gizi dengan memperhitungkan komposisi umur pada beberapa kelompok umur balita. Jurnal Epidemiologi Indonesia 7 (3), 2005.

5. Penny FB. Using the new World Health Organization growth standards: Differences from 3 countries. J. Pediatr Gastroenterol Nutr 2008 Mar, 46 (3): 316-21.

6. Schwarz NG, Grobusch MP, Decker ML, Goesch J, Poetschke M, Oyakhirome S, et al. WHO 2006 child growth standards: implications for the prevalence of stunting and underweightfor-age in a birth cohort of Gabonese children in comparison to the Centers for Disease Control and Prevention 2000 growth charts and the National Center for Health Statistics 1978 growth references. Public Health Nutr 2008 July; 11 (7): 714-9.

7. de Onis $M$, Onyango AW, Borghi $E$, Garza C, Yang H; WHO Multicentre Growth Reference Study Group. Comparison of the World Health organization (WHO) Child Growth Standards and the National Center for Health Statistics/WHO international growth reference: Implication for child health programmes. Public Health Nutr. 2006, Oct 9 (7): 942-7.

8. Prost MA, Jahn A, Floyd S, Mvula $\mathrm{H}$, Mwaiyeghele $\mathrm{E}$, et al. Implication of new $\mathrm{WHO}$ growth standards on identification of risk factors and estimated prevalence of malnutrition in rural Malawian infants. PLos One 2008, Jul 16, 3 (7): e2684.

9. Seal A, Kerac M. Operational implications of using 2006 World Health Organization growth standards in nutrition programmes: secondary data 
analysis. British Medical Journal 2007; 334: 733 .

10. Isanaka S, Villamor E, Shepherd S, Grais RF. Assessing the impact of the introduction of the World Health Organization Growth Standards and weight-for-height z-score criterion on the response to treatment of severe acute malnutrition in children: Secondary data analysis. Pediatrics 2008123 (1): e54-e59.

11. Worl Health Organization. The WHO Child Growth Standards. Avaliable from www.who.int/childgrowth/en (cited 2008 July 8). 